\title{
Morphology and Vascularization of the Gastric Compartments in Three-Toed Sloth (Bradypus torquatus Illiger, 1811)
}

\author{
Morfología y Vascularización de los Compartimentos Gástricos \\ en Osos Perezosos de Tres Dedos (Bradypus torquatus Illiger, 1811)
}

"L. C. Rezende; "J. M. Monteiro; **P. Carvalho; ${ }^{* *}$ J. R. Ferreira \& *M. A. Miglino

REZENDE, L. C.; MONTEIRO, J. M.; CARVALHO, P.; FERREIRA, J. R. \& MIGLINO, M. A. Morphology and vascularization of the gastric compartments in three-toed sloth (Bradypus torquatus Illiger, 1811). Int. J. Morphol., 29(4):1282-1290, 2011.

SUMMARY: The macroscopic anatomy and vascularization of the stomach compartments of Bradypus torquatus were examined in five animals from the University of São Paulo College of Veterinary Medicine and Zootechny collection. The method included aqueous perfusion of the arterial network, colored latex injection, fixation in formaldehyde (10\%) and preservation in Laskovisk solution. Dissections were performed under mesoscopic light and photo documentations were performed for description and data analysis. In these animals, the largest abdominal organ was the stomach, which internally presented the cardiac, fundic and prepyloric regions, subdivided in six compartments (cardiac right, middle and left; fundic; pre-pyloric I and II). The stomach was irrigated by the left gastric and celiac arteries, which are ventral visceral branches of the abdominal aorta. These arteries emerged in the retroperitoneal region and reached the viscera through the mesogastric region, distributed in the large and small stomach curvatures, in the spleen and the pancreas. The primary collateral branches of the left gastric artery are directed to the large stomach curvature, and the celiac artery irrigated the spleen, the pancreas and the small stomach curvature. The vascular pattern differed in some aspects from that observed in the other multicavity stomachs of recent vertebrates.

KEY WORDS: Digestive tract; Stomach; Celiac artery; Bradypodidae; Xenarthra.

\section{INTRODUCTION}

Complex organisms have developed extremely sophisticated digestive tract models, due to their functional requirements. This system represents an example of how peritoneal serosa and the vascular network became specialized due to the evolution of the types of organs that composed each organism: the pre-stomachs, stomachs, coelom, mesenteries and various mucosal adaptations. Considering the existence of the superorder Xenarthra in Central and South America (Gardner, 2007; Gaudin \& MacDonald, 2008) and the particularities of the body design and feeding habit of sloths, it was decided to study the morphology and the stomach blood supply model of Bradypus torquatus.

The various mammalian orders exhibit stomachs with extremely variable forms (Leghissa, 1975; Langer, 1984), presenting aspects of dilated pouches in their primitive form, with two curves and derived from the anterior intestine. It is known that various forms of the gastric compartments are specialized to fulfill specific requirements of animal digestion, depending on the animal's manner of feeding (herbivore, carnivore or omnivore). Furthermore, digestion, as well as the storage and expulsion of excrement, require coelom and mesentery adjustment, including that related to the blood supply (Grassé, 1965; Garcia \& Leal, 2003; Hildebrand \& Goslow, 2006). To guarantee the oxygen and glucose supply, the arteries derived from the celiac trunk and the cranial mesenteric are emphasized to provide nutrition to the stomach, spleen, pancreas and the anterior and middle intestines (Grassé, 1955; Moore \& Persaud, 2008). Some of these vessels were described in rodents and chelonians (Rodrigues et al., 2003; Culau et al., 2008). Studies on digestive tract morphology in Xenarthra refer to the morphology and vascularization of these structures without specifying aspects of the origin, route, destination or domain territory of the arteries destined for gastric compartments (Britton, 1941; Grassé, 1955; Langer, 1984; Foley et al., 1995; Diz et al., 2006; Souza et al., 2010).

\footnotetext{
* Departament of Surgery, Veterinary Medicine College and Zootecny, University of São Paulo, Brazil.

** Laboratory of Mesoscopy, Faculty of Medicine, University of Brasília, Brazil.
} 
Based on the premise that the stomach in general was derived from the anterior intestine and that the vessels originating from the celiac artery reached it through the mesogastrium (Langer, 1979a; Latshaw, 1987; Langer, 2002; Hyttel et al., 2010), we studied the external morphology, the visceral topography in relation to the abdominal cavity and its relation with the feeder arteries in $B$. torquatus.

\section{MATERIAL AND METHOD}

This descriptive study dealt with the gastric compartments of five three-toed sloths of the Bradypus torquatus species (Illiger, 1811), from the Veterinary Anatomy collection of the University of São Paulo College of Veterinary Medicine and Zootechny. The animals that died from natural causes were donated by the Zoobotanical Reserve (Matinha) of Ilhéus/Itabuna, under the responsibility of the Executive Commission of the Cacoa Farming Plan. The dissections were completed under mesoscopic light (Lts-Mod. 3700®) and were photo-documented with a digital camera (Nikon D40®). The thoracic aorta was perfused with warm water $\left(40^{\circ} \mathrm{C}\right)$ and injected with colored latex (Neoprene 650® and Sulvinil Corante 2350-0003®). After this process, the cadavers were fixed in formaldehyde solution (10\%) and preserved in Laskovisk solution. To analyze the external morphology data, the stomach topography, its relations, settings, subdivisions, as well as the arterial origins and the trajectory of these from the retroperitoneal region were considered. Based on data compiled from the literature (Table I) compared to those collected in this sample, the following stomach subdivisions were established in order to analyze the results: cardiac stomach subdivided in right, middle and left parts; fundic stomach and pre-pyloric stomach I and II. The anatomical denomination followed the Nomina Anatomica Veterinaria (International Committee on Veterinary Gross Anatomical Nomenclature, 2005) criteria in those aspects that could be compared to this species.

\section{RESULTS AND DISCUSSION}

Upon analyzing and discussing the results of this study, the stomach topography, its abdominal wall attachments, the morphology of its compartments and vascularization details were compared to those of other described vertebrates.

A sequence of anterior intestinal dilatations resulted in differentiation of the stomach, as established by Kent (1954) and Hyttel et al. Some authors correlated the size and digestive tract volumetric capacity, or part of it, with the body proportions. It can be interpreted from this analysis that compared to other animals, particularly among herbivores, Bradypus torquatus exhibited a voluminous stomach (Fig. 1A, B) in relation to the liver and the small and large intestines (Grassé, 1955; Langer, 1979a, 1987; Langer, 2002; Garcia \& Leal; Clauss et al., 2005) and to the peritoneal cavity in general.

Table I. Division of the Bradypus torquatus stomach compartments, in comparison with the Bradypus trydactylus stomach, from data compiled from the literature. Schweigger, 1812 (Testudinata-Prlomedusidae). Source: research data FMVZ/USP; FM/UNB, 2010.

\begin{tabular}{|c|c|c|c|c|c|c|}
\hline Bradypus & \multicolumn{6}{|c|}{ Bradypus trydactylus: data compiled from the literature } \\
\hline Rezende et al. & Britton, 1941 & Grassé, 1955 & Andrade, 1972 & Langer, 1984 & $\begin{array}{l}\text { Foley et al., } \\
1995\end{array}$ & $\begin{array}{l}\text { Pacheco et al., } \\
2007\end{array}$ \\
\hline \multirow{3}{*}{ Cardiac s. } & \multirow{3}{*}{ Main stomach } & Middle & Cardiac I & \multirow{2}{*}{ Central sack } & \multirow{2}{*}{ Central sack } & \multirow{3}{*}{ Pouch } \\
\hline & & blindsac & Cardiac II & & & \\
\hline & & Left blindsac & Cardiac III & Ligation sack & Ligation sack & \\
\hline Fundic s. & Appendix & Right blindsac & Fundus & Fundus & Fundus & Fundus \\
\hline \multirow{2}{*}{ Pre-pyloric s. } & \multirow{2}{*}{ Pre-pyloric chamber } & Glandular s. & Pyloric I s. & \multirow{2}{*}{ Pre-pyloric s. } & \multirow{2}{*}{ Pre-pyloric s. } & $\begin{array}{l}\text { Pre-pyloric } \\
\text { glandular } \\
\text { portion }\end{array}$ \\
\hline & & Muscular s. & Pyloric II s. & & & $\begin{array}{l}\text { Pre-pyloric } \\
\text { muscular } \\
\text { portion }\end{array}$ \\
\hline
\end{tabular}

Note: utilized abbreviation: $s=$ stomach. 
When referring to the body proportions, Britton established that the B. tridactylus stomach would correspond to between 20 to $30 \%$ of its body mass. In turn, Grassé (1955) described similar proportions for other recent vertebrates. In Figure 1, through a series of images, the $B$. torquatus stomach was topographically documented, clearly demonstrating that its proportions extrapolate the total volume occupied by the other viscera. The above-mentioned author demonstrated that in Bradypus ontogenetic development, the liver gradually yielded space in the coelomic abdominal region to the stomach, which was evident in the studied animals, whose liver exhibited reduced size in relation to the other abdominal viscera (Fig. $1 \mathrm{E}, \mathrm{F})$.

Kent stated that the mammalian stomach exhibits cardiac, fundic and pyloric regions, in accordance with the type of glands present; however, there is not always correspondence of the morphologic classification with the histological classification, similar to that observed by Langer (1984) in B. tridactylus. The B. tridactylus gastric compartment classification diverged among the authors (Britton; Grassé, 1955; Andrade, 1972; Langer, 1984; Foley et al.; Pacheco et al., 2007), whose compiled data (Table I) were used as the basis for the interpretation performed in this study. The macroscopic observations of the B. torquatus stomach, the above-mentioned literature and the Nomina Anatomica Veterinaria allowed the proposal of the following division and situation of the stomach compartments in this animal: the cardiac stomach was situated around the cardiac region, subdividing itself in three sacks (right, middle, left); the fundic stomach, represented by the right lateral sack, continuous with the diverticulum, projecting caudal-laterally to the left (Fig. 1A, B) and the pre-pyloric stomach, subdivided into glandular (I) and muscular (II) parts (Fig. 2B, E, F). The latter showed not only the pyloric antrum, but also a dilated segment that preceded the pyloric canal. A distal constriction was emphasized in the stomach passage to the duodenum, which contains a sphincter muscle (pylorus) and a communication with the duodenum through the pyloric orifice (Fig. 2F). With regard to the stomach position and fixation, its relationship with the principal subdivision of the peritoneal cavity was considered by Hyttel et al. as the larger sack and the omental bursa. Most of the B. torquatus stomach was situated in the larger sack, equivalent to the peritoneal cavity (Fig. 1A, B). Upon fixation of the stomach, the peritoneum exhibited hepatoduodenal, gastrosplenic and hepatogastric dependencies situated dorsally to the named viscera (Fig. 1C, D, E, G). The omental bursa, in its dorsal recess, accommodated the liver and appeared to be limited by the lesser omentum (Fig. 3D) and the visceral peritoneum of the stomach. Delamination of the visceral peritoneum did not occur in the region of the ventral curvature of the stomach in the caudal direction, in the interior of the large sack of the peritoneal cavity. B. torquatus did not exhibit greater omentum, in contrast to other vertebrates (Kent; Grassé, 1955; Bogart \& Ort, 2008). The peritoneal recess of the stomach (mesogastrium) fixed the viscera lateralcranially to the diaphragm (Fig. 1C, F).

The vessels that originated from the abdominal aor$\mathrm{ta}$, in the retroperitoneum, penetrated through the mesogastrium, reaching the umbilicus cranial curvature of the cardiac stomach (Fig. 3A, B). At the same time, the peritoneum supported the stomach in the anatomical position through the mesogastrium and allowed the transit of vessels and nerves. Langer (1979b) reported the presence of mesogastrium and gastrolienal ligaments in marsupials. The spleen and the pancreas were adhered to the left cardiac stomach and to the pre-pyloric stomach through the gastrosplenic and gastropancreatic ligaments (Fig. 1G, 3B, $3 \mathrm{C}, 4)$.

Ontogeny studies revealed that, in recent vertebrates, the celiac trunk supplies the caudal portion of the anterior intestine; moreover, the stomach is derived from the celiac trunk (Noden \& Lahunta, 1985; Latshaw; Hyttel et al.). The liver started to develop in the transversal septum in association with the diaphragm. The spleen developed with the splenic artery as one of the celiac trunk branches (Bogart \& Ort; Hyttel et al.). In B. torquatus, it was curious to note the lack of a celiac trunk. Two supplemental blood sources for the stomach were identified to be dependent on the retroperitoneal aorta: the left gastric artery, following the cranial curvature of the stomach and the celiac artery, following the caudal curvature of the stomach, spleen and pancreas (Fig. 3A, B). This aspect, which is contradictory to many studies in recent mammals, indicated that during embryonic development in the caudal extremity of the anterior intestine, the existence of the celiac trunk artery is responsible for the nutrition of the stomach, liver, spleen, pancreas and part of the duodenum (Nelsen, 1953; Hyttel et al.). The liver in B. torquatus was nourished by the first dorsal collateral branch of the common mesenteric artery, contrary to studies in other vertebrates. The vascularization of this digestive tract in general would depend on the vessels that primitively supplied the caudal extremity of the anterior intestine and the cranial extremity of the middle intestine: the celiac trunk and the cranial mesenteric artery (Nickel \& Schummer, 1977). In this animal, the celiac artery was bifurcated for a half-centimeter after its emergence in the hilar region of the stomach in the mesogastric interior. This artery is subdivided to the right gastric and splenic regions, following the caudal curvature of the stomach (Fig. 3A, B, C, E, F). 

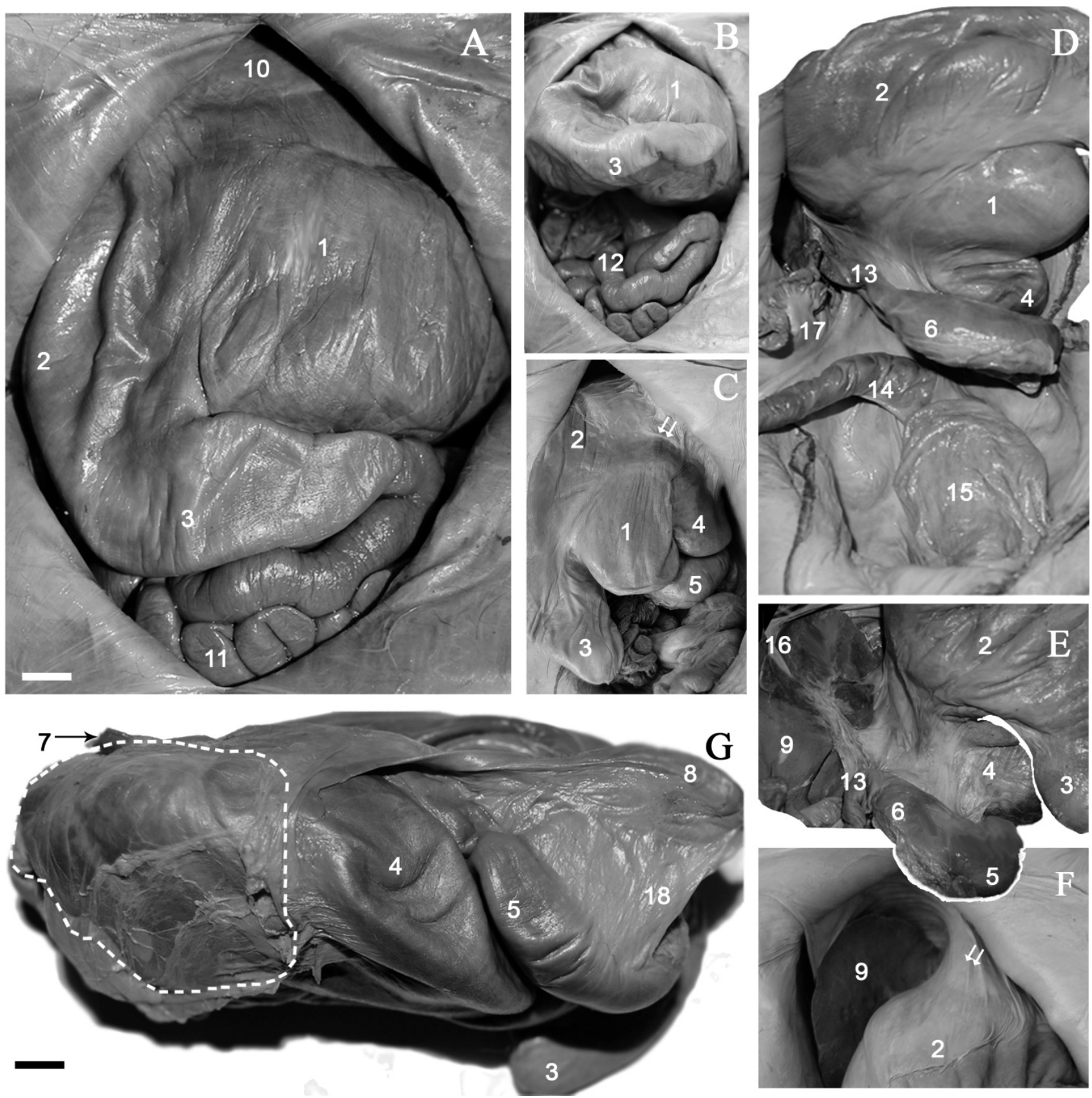

Fig. 1. Opened peritoneal cavity from the external tissue to the pubic bone (A, B, C, D, F) and the details of the isolated stomach (E, G). Emphasis on the ventral (A, B, F), dorsal (D), left lateral $(\mathrm{C}, \mathrm{G})$ and right lateral (E) views. Images display: medial cardiac stomach (1), fundic stomach (2), diverticulum (3), left cardiac stomach (4), pre-pyloric stomach I (5), pre-pyloric stomach II (6), esophagus (7), spleen (8), liver (9), diaphragm (10), small intestine (11), large intestine (12) duodenum (13), rectum (14), urinary bladder (15), mesogastric (I), region of mesogastric coalescence with the abdominal wall (---), falciform ligament (16), mesenteric (17), gastrosplenic ligament (18). $\mathrm{Bar}=1 \mathrm{~cm}$.

The right gastric artery (Fig. 3A, B, E, F) followed the cranial curvature formed between the cardiac and fundic stomach compartments. It irrigated the greater part of the middle cardiac stomach, in transit through the ventral curvature and the fundic stomach, reaching the diverticulum
(Fig. 3E, F). The pre-pyloric stomach was nourished by two branches derived from the right gastric artery in the small curvature (Fig. 3A) and by various branches derived from the splenic artery, which approached the large curvature through the gastrosplenic ligament (Fig. 3C). The pancreas 


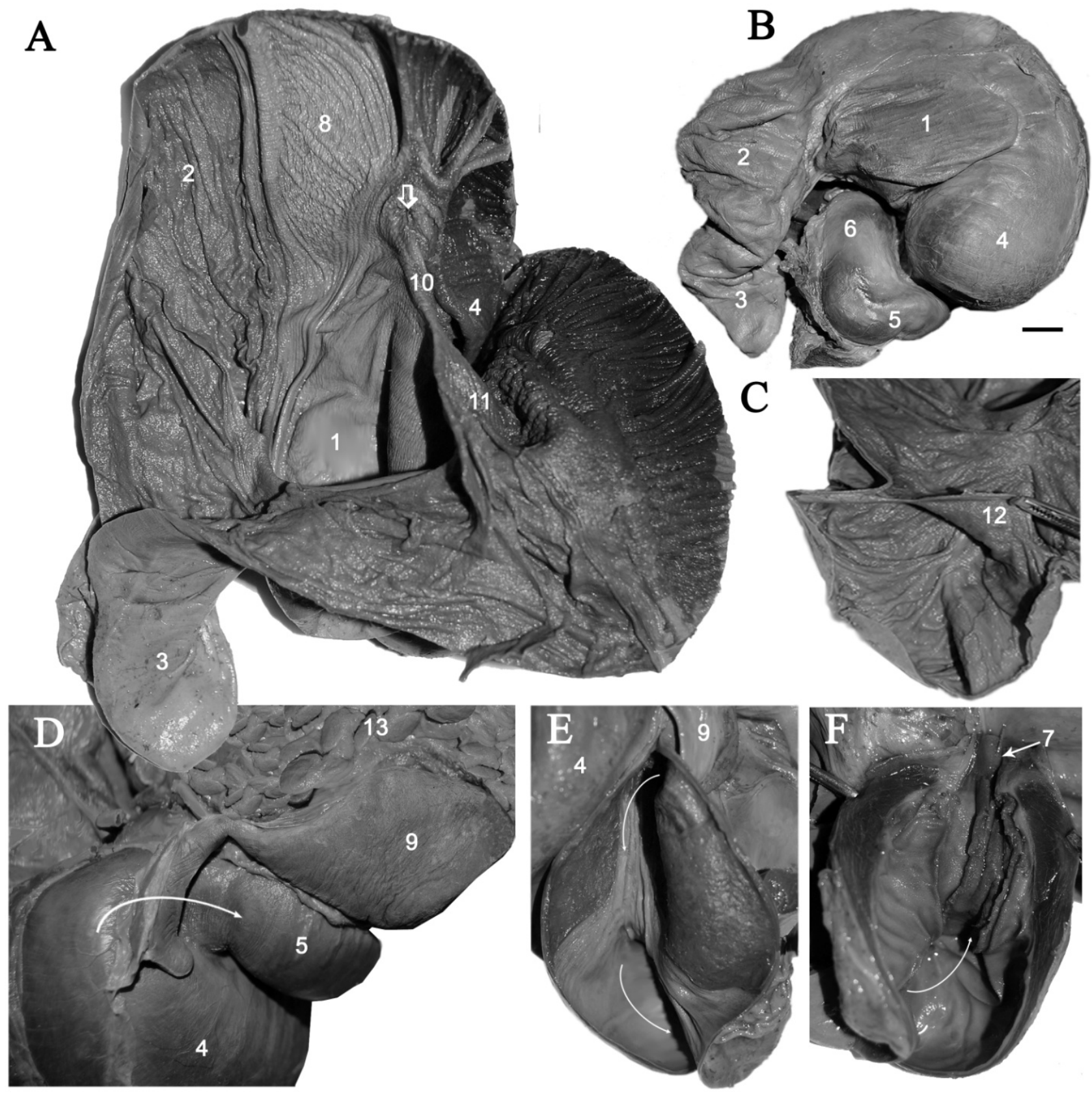

Fig. 2. Internal and external morphological aspects of the Bradypus torquatus stomach. Internal cranial-caudal view (A), external cranialcaudal (B), left lateral view of the stomach (D), open diverticulum (C), pre-pyloric stomach I (E) and pre-pyloric stomach II (F). External views of: middle cardiac stomach (1), fundic stomach (2), diverticulum (3), left cardiac stomach (4), pre-pyloric stomach I (5), pre-pyloric stomach II (6), and pyloric sphincter (7). Also note the mucosa of the right cardiac stomach (8), spleen (9), the annular thickening of the wall (10) and the wall that internally separates the middle cardiac stomach from the left cardiac stomach, arriving at the pre-pyloric stomach I (11), division fold of diverticulum (12), pancreas (13); the arrows (P) in D, E and F indicate the direction of food transit. Bar= $1 \mathrm{~cm}$.

received nutrition through collateral branches from the splenic and right gastric arteries.

Particular differences were found between $B$. torquatus and other mammals in relation to cranial floor vascularization of the peritoneal cavity. The gastric and celiac vessels were not directly involved with the liver and duodenum nutrition, diverging from the description in chelonians (Rodrigues et al.; Santos et al., 2004), rodents (Culau et al.), suidae (Cavalcante Filho et al., 1998) and 


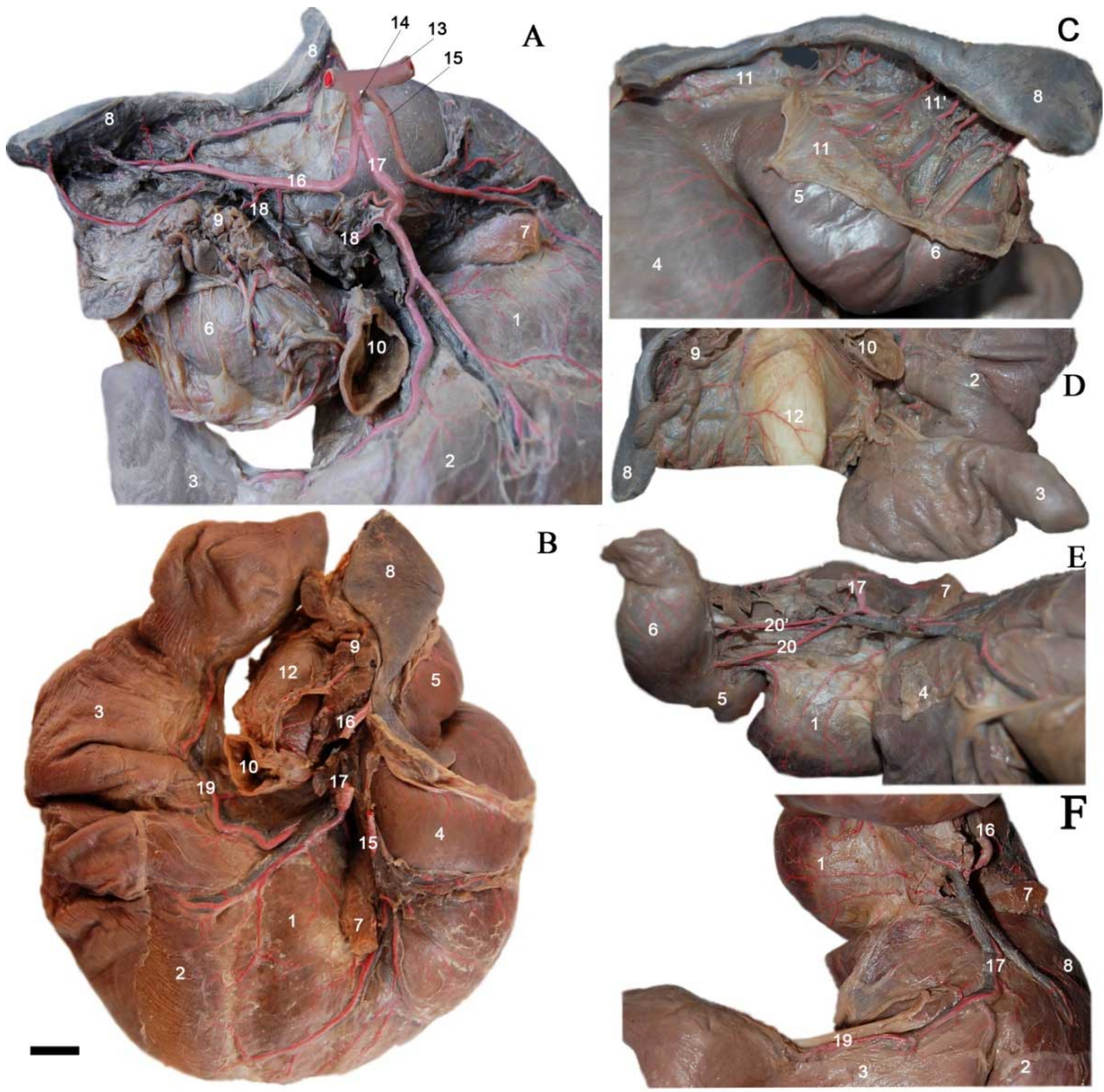

Fig. 3. Morphological aspects and abdominal aorta branches destined for the Bradypus torquatus stomach. Left dorsal-medial view (A, D), cranial-caudal (B), left lateral (C) and medial (E, F). Please observe: middle cardiac stomach (1), fundic stomach (2), diverticulum (3), left cardiac stomach (4), pre-pyloric stomach I (5), pre-pyloric stomach II (6), esophagus (7), spleen (8), pancreas (9), duodenum (10), gastrosplenic ligament (11), short gastric arteries (11'), abdominal lesser omentum (12), abdominal aorta (13), celiac artery (14), left gastric artery (15), splenic artery (16), right gastric artery (17), pancreatic branches (18), diverticular artery (19), pre-pyloric artery (20), pyloric (20'). Bar= $1 \mathrm{~cm}$.

some ungulates (MacDonald \& Hatman, 1983; Miglino \& Di Dio, 1993; Machado et al., 1997, 2000). The particularities in B. torquatus stomach vascularization were not compared, due to the absence of reports.
In relation to the macroscopic anatomy of $B$. torquatus, the formation of many transversal folds was observed in the fundic stomach mucosa (Fig. 2A), similar to that observed in B. tridactylus by Dulzetto (1968). A 
longitudinal fold was observed in the diverticulum, which divided it in two compartments (Fig. 2C).

Some studies have made comparisons, based on glandular structure and compartmentalization of the stomach mucosa, of Artiodactyla with those of other mammals. The authors defined the morphophysiology of these regions as follows: glandular, cardiac, acid producers and pyloric (Kent; Vallenas et al., 1971; Langer, 1974; Nickel \& Schummer; Langer, 1987). The glandular function and activity reports in different stomach regions in the vertebrate series demonstrate that gastrointestinal tract differentiation appears to maintain important relationships with the cardiac glands. These first appeared in mammals, occupying regions that were occupied by fundic glands in the primitive stomachs (Bensley, 1910). Considering that B. torquatus exhibited a primitive stomach model (Britton), it was interesting to observe that the fundus stomach was occupied by cardiac glands, according to the proposal by Langer (1984). The cardiac stomach in turn was considered aglandular and the pre-pyloric stomach presented as characteristic acidproducing glands. The internal morphology of the mucosa in the various gastric compartments of the studied animals was macroscopically documented (Fig. 2).

The B. tridactylus stomach was the object of biochemical, histological and histochemical analysis by Andrade, whose study was occupied with the presence

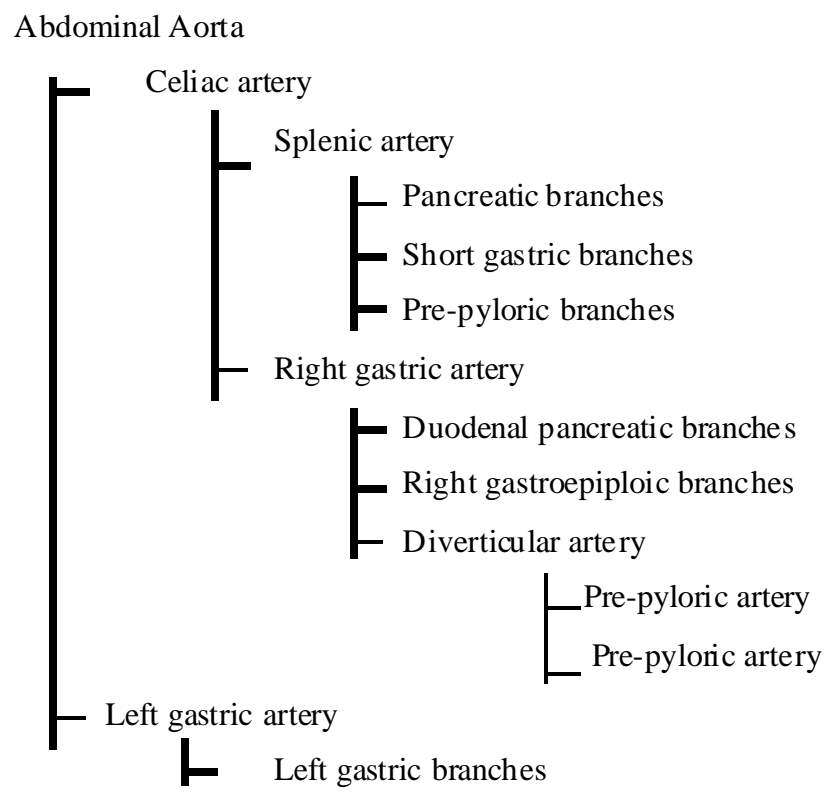

Fig 4. Branches of the abdominal aorta destined for the stomach of Bradypus torquatus. of polysaccharides and proteins. The study also considered pepsin dosage in the seven gastric compartments: cardiac stomach I, II, III; fundic stomach; diverticulum; pyloric stomach I and II. The pepsinogenic activity of the pyloric stomach was confirmed to be similar in sloths of the Choloepus genus by Dennis et al. (1967).

Enzymatic digestion was described in the Bradypodidae (Pacheco et al., 2007) and confirmed as differentiation or organic specialization by Langer (2002). Langer (2003) analyzed animals from the Pilosa order, establishing degrees of digestive tract differentiation and demonstrating morphophysiological adaptations in these animals after the initiation of herbivore feeding overlap with the lactation period.

\section{CONCLUSION}

It is believed that the restricted diet of $B$. torquatus could explain the morphology of the viscera in the abdominal cavity cranial compartment. This animal has habits of arboreal life, restricted foliage feeding and slow movements, living in the treetops, far from predators. The ecology of its life may be one of the aspects that explain the fragility of the stomach parietal attachments, absence of greater omentum and the round liver ligament, different from that described in recent vertebrates.

Both the morphological and biochemical studies and the evolutionary analyses made by the authors in this study allowed us to consider that $B$. torquatus stomach is primitive in relation to recent vertebrates; that the celiac and right gastric arteries, individual branches of the aorta, merged to form the celiac artery in recent vertebrates. The liver was smaller because it performs simplified metabolic processes in relation to the vertebrates, which exhibit more complex metabolism.

\section{ACKNOWLEDGEMENTS}

The authors thank the Zoobotanical Reserve (Matinha) of Ilhéus/Itabuna, under the responsibility of the Executive Commission of the Cacao Farming Plan, which provided the University of São Paulo with the sloths used in this study. 
REZENDE, L. C.; MONTEIRO, J. M.; CARVALHO, P.; FERREIRA, J. R. \& MIGLINO, M. A. Morfología y vascularización de los compartimentos gástricos en osos perezosos de tres dedos (Bradypus torquatus Illiger, 1811). Int. J. Morphol., 29(4):1282-1290, 2011.

RESUMEN: Fue descrita la anatomía macroscópica y vascularización de los compartimientos del estómago en 5 Bradypus torquatus, animales pertenecientes al acervo de la Facultad de Medicina Veterinaria y Zootecnia de la Universidad de São Paulo - Brazil. El método incluyó: perfusión acuosa de la red arterial, inyección de látex coloreado, fijación en formaldehido (10\%) y conservación en solución de Laskovisk. Para la descripción y análisis de los datos se realizaron disecciones bajo mesoscopía de luz y archivos fotográficos. Los animales presentaron el estómago como la víscera abdominal más abundante, que posee internamente las regiones: cardiaca, fúndica y pre-pilórica, subdivididas en seis compartimientos (cardiaco, derecho, medio e izquierdo; fúndico; pre-pilórico I y II). Estaba irrigado por las arterias gástricas izquierda y celiaca, que son ramas viscerales ventrales de la parte abdominal de la aorta. Estas arterias emergían en el retroperitoneo y a tráves del mesogastrio alcazaban las vísceras distribuyéndose en la gran y pequeña curvatura del estómago, bazo y páncreas. Las ramas colaterales primarias de la arteria gástrica izquierda estaban destinadas a la gran curvatura del estómago y los de la arteria celíaca irrigaban el bazo, páncreas y pequeña curvatura del estómago. El estándar vascular del Bradypus torquatus más conocido como oso perezoso de tres dedos demostró ser diferente, en algunos aspectos, al de otros estómagos pluricavitarios en vertebrados.

\section{PALABRAS CLAVE: Tubo digestivo; Estómago; Arteria celíaca; Bradypodidae; Xenarthra.}

\section{REFERENCES}

Andrade, E. P. Contribuição ao Estudo Anatômico, Histológico, Histoquímico e Bioquímico da Mucosa Gástrica da Preguiça (Bradypus tridactylus). São Paulo, Escola Paulista de Medicina Universidade Federal de São Paulo, 1972.

Bensley, R. R. The cardiac glands of the mammalian stomach. Anat. Rec., 4:375-90, 1910.

Bogart, B. L. \& Ort, V. H. Anatomia e Embriologia. Rio de Janeiro, Elsevier, 2008. pp.147-202.

Britton, S. W. Form and function in the sloth. Quart. Rev. Biol., 16(1):13-34, 1941.

Cavalcante Filho, M. F.; Miglino, M. A.; Machado, G. V.; Bevilacqua E. \& Neves, W. C. Estudo comparativo sobre o suprimento arterial do estômago do queixada (Tayassu pecari) e do cateto (Tayassu tajacu) [Linnaeus, 1789]. Braz. J. Vet. Res. Anim. Sci., 35(1):20-4, 1998.

Clauss, M.; Hummel, J.; Vercammen, F. \& Streich, W. J. Observations on the macroscopic digestive anatomy of the Himalayan tahr (Hemitragus jemlahicus). Anat. Histol. Embryol., 34(4):276-8, 2005.

Culau, P. V. O. Azambuja, R. C. \& Campos, R. Ramos colaterais viscerais da artéria aorta abdominal em Myocastor coypus (nutria). Acta Scient. Vet. 36:241-7, 2008.

Dennis, C.; Jeuniaux, C.; Gerebtzoff, M. A. \& Goffart, M. La digestion stomacale chez un paressux, l'unau Choloepus hoffmanni Peters. Annls. Soc. R. Zool. Belg., 97:9-29, 1967.

Diz, M. J. O.; Quse, B. \& Gachen, G. G. Registro de medidas y pesos del tubo digestivo de un ejemplar de Chaetophractus villosus. Edentata, 7:23-5, 2006.
Dulzetto, F. Anatomia Comparata dei Vertebrati. Bologna, Edizione Calderini, 1968.

Foley, W. J.; Engelhardt, W. V. \& Charles-Dominique, P. The passage of digesta, particle size, and in vitro fermentation rate in the three-toed sloth Bradypus tridactylus. (Edentata:Bradypodidae). J. Zool., 236:681-96, 1995.

García, C. G. C. \& Leal, M. L. Morfología del estómago e intestino grueso del báquiro de collar (Tayassu tajacu). Veterinaria Trop., 28(2):117-34, 2003.

Gardner, A. L. Cohort placentalia owen, 1837. Magnorder Xenarthra Cope, 1889. In: Mammals of South America, Marsupials, Xenarthrans, Shrews, and Bats. Chicago, University of Chicago Press, 2007. pp.127-77.

Gaudin, T. J. \& Mcdonald, H. G. Morphology-based investigation of the phylogenetic relationships among extant and fossil Xenarthrans. In: Vizcaíno S. F. \& Looughry, W. J. The biology of the Xenarthra. Gainesville, University Press of Florida, 2008.

Grassé, P. P. Ordre des Édentés. In: |Grassé P. P. (Ed.) Traité de Zoologie Anatomie, Systématique, Biologie. Paris, Masson et Cie Éditeurs, 1955. pp. 1182-246.

Grassé, P. P. Cavité Générale. In: Traité de Zoologie. Anatomie Comparé, Tome II. Vértebres. Paris, Masson et Cie Éditeurs, 1965. pp. 391-5.

Hildebrand, M. \& Goslow, G. Análise da Estrutura dos Vertebrados. São Paulo, Atheneu, 2006. pp.195-9.

Hyttel, P.; Sinowatz, F. \& Vejlsted, M. Development of the gastropulmonary system. In: Essentials of domestic animal embryology. Edinburg, Saunders Elsevier, 2010. pp. 216-48. 
Kent, G. C. Digestive system. In: Kent G. C. (Ed.). Comparative anatomy of the vertebrates. New York, McGraw-Hill Book Company, 1954. pp.305-29.

Langer, P. Stomach evolution in the Artiodactyla. Mammalia, 38(2):295-314, 1974.

Langer, P. Adaptational significance of the forestomach of the collared peccary, Dicotyles tajacu (L. 1758) (Mammalia: Artiodactyla). Mammalia 43: 235-246, 1979a.

Langer, P. Functional anatomy and ontogenetic development of the stomach in the macropodine species Thylogale stigmatica and Thylogale thetis (Mammalia: Marsupialia). Zoomorphologie, 93:137-51, 1979b.

Langer, P. Comparative anatomy of the stomach in mammalian herbivores. Q. J. Exp. Physiol., 69(3):615-25, 1984.

Langer, P. Evolutionary patterns of Perissodactyla and Artiodactyla (Mammalia) with different types of digestion. Z. Zool. Syst. Evolutionsforsch., 25(3):212-36, 1987.

Langer, P. The digestive tract and life history of small mammals. Mammal. Rev., 32:107-31, 2002.

Langer, P. Lactation, weaning period, food quality, and digestive tract differentiations in Eutheria. Evolution, 57(5):1196-215, 2003.

Latshaw, W. K. Veterinary developmental anatomy: a clinically oriented approach. Missouri, Mosby Company, 1987.

Leghissa, S. Principi di Morfologia dei Vertebrati. 2nd ed. Torino, Unione Tipográfico-Editric, 1975.

Macdonald, A. A. \& Hartman, W. Comparative and functional morphology of the stomach in the adult and newborn pigmy hippopotamus (Choeropsis liberiensis). J. Morphol., 177(3):269-76, 1983.

Machado, M. R. F.; Miglino, M. A. \& Honsho, D. K. Ramificação da artéria celíaca no estômago de bubalinos S.R.D (Bubalus bubalis- Linnaeus, 1758). Rev. Unimar, 19:565-71, 1997.

Machado, M. R. F.; Miglino, M. A.; Cabral, V. P. \& Araújo, N. Origem das artérias celíaca e mesentérica cranial em bubalinos (Bubalus bubalis, L. 1758). Braz. J. Vet. Res. Anim. Sci., 37:99104, 2000.

Miglino, M. A. \& Didio, L. J. A. Artérias dos estômagos de fetos de bovinos da raça Nelore. Braz. J. Vet. Res. Anim. Sci., 30:9$15,1993$.

Moore, K. L. \& Persaud, T. V. N. O sistema digestório. In: Embriologia Clínica. 8a ed. Rio de Janeiro, Elsevier, 2008. pp.214-44.
Nelsen, O. E. The development of the coelomic cavities. In: Nelsen O. E. (Ed.). Comparative Embryology of the Vertebrates. New York, McGraw-Hill, 1953. pp.857-73.

Nickel, R. \& Schummer, A. Anatomy of the Domestic Mammals. Hamburg, Verlog Paul Parey, 1977.

Noden, D. M. \& Lahunta, A. Embryology of domestic animals: developmental mechanisms and malformations. Baltimore, Williams \& Wilkins, 1985.

International Committee on Veterinary Gross Anatomical Nomenclature (I.C.V.G.A.N.). Nomina Anatomica Veterinaria. $5^{\text {th }}$ ed. Available at http://www.wava-amav.org/Downloads/ nav-_2005.pdf(20 Set 2010), 2005.

Pacheco, M. A.; Concepción, J. L.; Rangel, J. D.; Ruiz, M. C.; Michelangeli, F. \& Domínguez-Bello, M. G. Stomach lysozymes of the three-toed sloth (Bradypus variegatus), an arboreal folivore from the Neotropics. Comp. Biochem. Physiol. A Mol. Integr. Physiol., 147(3):808-19, 2007.

Rodrigues, R. F.; Miglino, M. A. \& Melo, A. P. F. Vascularização arterial do trato gastrointestinal da Trachemys script elegans, Weid, 1838. Braz. J. Vet. Res. Anim. Sci., 40(1):63-68, 2003.

Santos, A. L. Q.; Mundim, A. V.; Moraes, F. M.; Alvarenga, G. J. R.; Marques, F. K.; Borges, K. M. \& Alves Junior, J. R. F. Origem e ramificações das artérias mesentéricas cranial e caudal em tartaruga da Amazônia Podocnemis expansa Schweigger, 1812, (Testudinata-Pelomedusidae). Arch. Vet. Sci., 9: 49-53, 2004.

Souza, A. L. R.; Rezende, L. C.; Mortoza, A. R. \& Ferreira, J. R. Modelo de suprimento sanguíneo do intestino grosso do tamanduá bandeira (Myrmecophaga tridactyla). Cienc. Rural, 40:541-7, 2010.

Vallenas, A.; Cummings, J. F. \& Munnell, J. F. A gross study of the compartmentalized stomach of two new-world camelids, the llama and guanaco. J. Morph., 134(4):399-424, 1971.

\section{Correspondence to: \\ J. R. Ferreira \\ Campus Darcy Ribeiro \\ Asa Norte, CEP 70910-900 \\ Brasília, DF \\ BRAZIL}

Tel: 5561 3107-1912

Email: jussararocha@unb.br

Received: 17-06-2011

Accepted: 05-09-2011 